\title{
Measuring the Sustainable Entrepreneurial Performance of Textile-Based Small-Medium Enterprises: A Mediation-Moderation Model
}

\author{
Sidney Mangenda Tshiaba ${ }^{1, *(\mathbb{C},}$, Nianxin Wang ${ }^{1, *}$, Sheikh Farhan Ashraf ${ }^{2}{ }^{(\mathbb{D}}$, Mehrab Nazir $^{1}{ }^{1}$ and \\ Nausheen Syed ${ }^{3}$ \\ 1 School of Economics and Management, Jiangsu University of Science and Technology, Zhenjiang 212003, \\ China; Mehrabnazir9@gmail.com \\ 2 School of Management, Jiangsu University, Zhenjiang 212100, China; fhsheikh08@gmail.com \\ 3 Department of Business Administration, Government College Women University, Faisalabad 38000, Pakistan; \\ nausheen.dr@gmail.com \\ * Correspondence: sidneytshiaba@outlook.com (S.M.T.); nianxin.wang@gmail.com (N.W.)
}

check for updates

Citation: Mangenda Tshiaba, S.; Wang, N.; Ashraf, S.F.; Nazir, M.; Syed, N. Measuring the Sustainable Entrepreneurial Performance of Textile-Based Small-Medium Enterprises: A MediationModeration Model. Sustainability 2021, 13, 11050. https://doi.org/ $10.3390 /$ su131911050

Academic Editors: Claudio Sassanelli, Sergio Terzi and Marc A. Rosen

Received: 8 August 2021

Accepted: 29 September 2021

Published: 6 October 2021

Publisher's Note: MDPI stays neutral with regard to jurisdictional claims in published maps and institutional affiliations.

Copyright: (c) 2021 by the authors. Licensee MDPI, Basel, Switzerland. This article is an open access article distributed under the terms and conditions of the Creative Commons Attribution (CC BY) license (https:// creativecommons.org/licenses/by/ $4.0 /)$.

\begin{abstract}
This research aimed to examine the role of knowledge management practices in sustainable entrepreneurship performance. This study also investigated the relationships between six concepts: knowledge sharing behavior, innovative capacity, absorptive capacity, dynamic capability, opportunity recognition, and sustainable entrepreneurship. A self-administered questionnaire was used for data collection from 486 entrepreneurs randomly selected from textile-based SMEs in the Democratic Republic of the Congo (DRC). The findings show that knowledge management practices positively and significantly impact sustainable entrepreneurship performance and SMEs' dynamic capabilities. Moreover, opportunity recognition strengthens the relationship between SMEs' dynamic capabilities and sustainable entrepreneurship performance. This study offers valuable insights and directions for researchers and practitioners interested in the field of entrepreneurship.
\end{abstract}

Keywords: sustainable entrepreneurial performance; dynamic capabilities; opportunity recognition; knowledge sharing behavior; innovative capacity; absorptive capacity

\section{Introduction}

Across the world, the importance of sustainable entrepreneurship has increased as a potential solution to different problems. Practitioners claim that entrepreneurs may tackle issues caused by natural degradation by inventing new sustainable practices $[1,2]$. Sustainable entrepreneurship performance, in addition to success, is based on knowledge and represents an element of competitive advantage [3]. Knowledge management practices such as knowledge sharing behaviors, innovations, and absorption capacities build a relationship between entrepreneur capabilities and sustainable entrepreneurship performance [4]. According to Antunes and Pinheiro [5], knowledge management practices can help small and medium enterprises (SMEs) develop and prosper with better business performance in the long term.

Prior studies have examined the impact of knowledge management practices on sustainable entrepreneurship [6] and the relationship between leadership skills and sustainability. Moreover, knowledge-based theory (KBT) can efficiently manage and create unique dynamic capabilities which contribute to sustainable entrepreneurship performance [4]. Therefore, entrepreneurs with knowledge management practices will likely achieve good sustainable entrepreneurship performance [5]. Li [3] explained that the sharing, acquisition, and application of knowledge contribute to innovation and performance [7]. The knowledge management practices of entrepreneurs have progressively become of interest to researchers, especially in business studies, as a means of enhancing entrepreneurship performance $[8,9]$. 
When knowledge management engages in sustainability, the organization's attitude evolves, and social responsibility is valued equally to economic viability [10]. The significance of KMPs consolidating at the worldwide level demonstrates the convergence in the utilization of KMPs in organizations [11]. Knowledge management (KM) practices can be broken down into three sets, namely, knowledge sharing behavior, innovative capacity, and absorptive capacity [12-15]. Sustainable development techniques can be built on the foundation of knowledge management. Knowledge sharing behavior, innovative capacity, and absorptive capacity are considered vital attributes of knowledge management practices in sustainability criteria, especially in an entrepreneurial context [15]. As a result, businesses must rely more heavily on their knowledge-generating resources. In sustainable development, knowledge management practices are considered a new philosophy of development that attempts to improve engagement with social, economic, and environmental values [16,17]. The KMPs utilized in sustainability explain a transformation in the organization's stance when social and environmental responsibilities are held as equal to commercial viability. Knowledge management (hereafter known as KM) practices have become an essential source of enhancing the sustainable performance of organizations.

In this regard, $\mathrm{KM}$ can play a crucial role by facilitating the sharing of information among various time zones and geographical regions [18]. There is a growing need for approaches to improve KM processes and procedures throughout the assessment of environmental, social, and economic consequences, given the increased demand for sustainable entrepreneurial performance [19]. This study focused on the knowledge management practices contributing to many dimensions of sustainability that are best described in the literature.

Recent studies have emerged that integrate entrepreneurship with sustainability and encompass the broad concept of sustainable entrepreneurship, which includes financial, environmental, and moral ideals [20]. Due to the rapid changes in the environment, SME entrepreneurs confront a number of challenges in finding opportunities that might help them solve problems and improve their performance [3]. Small-medium enterprises (SMEs) can play a significant role in developing a country - they are generally considered a key pillar of economic development in developing countries [21]. Therefore, several entrepreneurial capabilities are essential to enhance sustainable entrepreneurial performance (SEP) and achieve organizational development goals [12]. Good SEP depends not only on the willingness and commitment to become an entrepreneur [22,23] but also on the knowledge and capabilities essential to becoming a sustainable entrepreneur [24].

Entrepreneurs have many opportunities to utilize the available resources for higher profitability and ensure their sustainable organizational performance [25]. Several studies have proven the potential role of SMEs in enhancing economic growth, wealth creation, and employment, particularly in emerging countries [26]. Therefore, it is necessary to explore the integrated relationship among several sustainable entrepreneurial success factors, particularly in developing countries such as the Democratic Republic of the Congo (DRC) [27]. SMEs have played a major part in contributing to this country's gross domestic product (GDP). Furthermore, the SME sector of the DRC represents $25 \%$ of the country's exports, $35 \%$ of manufacturing, and $53 \%$ of the hotel, restaurant, wholesaler, and retail trade sectors. Additionally, $20 \%$ of SMEs are active in the industrial sector, and $22 \%$ are engaged in the service sector.

SEP is directly associated with knowledge management practices: both SEP and knowledge management play a positive role in ensuring business growth [28,29]. Numerous studies suggested that improvement in SEP supports and sustains an organization's market value [30]. However, there are several fundamentals which are involved in SEP such as knowledge sharing behavior (KSB), innovative capacity (IC), and absorptive capacity (AC), which are directly related to the success of an entrepreneur [31]. The exchange of skills and experiences within an organization is known as KSB [32]. Information regarding organizational schedules, depositories, and repositories and across organizational boundaries is practiced and eventually relies on members' KSB for performance [33]. The 
sharing of knowledge in an organization depends on the organizational atmosphere and entrepreneurs' behavior, which is beneficial for sustainable performance [12]. When KSB is restricted, the gaps ascend, which creates hurdles in performances [34].

Prior studies illustrated that innovation and innovative capability (IC) are also related to SEP [35]. The linkage of inner capacity with abilities that comes with something new is known as IC-IC is directly correlated with the nature of SEP [35]. The IC of an individual comes in the form of entrepreneurship. Furthermore, entrepreneurs' strategic planning and absorptive and innovative capacities enhance SEP [36,37]. AC categorizes abilities and the assimilation and utilization of knowledge for SME performance. Entrepreneurs with AC can absorb knowledge from competitors and apply knowledge within their organization to enhance performance [36]. Researchers indicated that AC combines three necessary abilities: peripheral knowledge, understanding of knowledge, and integration of innovative knowledge for SEP [9]. These practices may help to manage the knowledge that can be used for achieving organizational goals [38]. Therefore, it is important to measure the impact of such knowledge management practices on the EP of SMEs.

However, studies have proved that an entrepreneur's dynamic capability (DC) has a vital role in increasing performance, which can be further availed by using organizational resources to create, design, and modify an organization according to market conditions and challenges $[39,40]$. DC replicates valuable resources such as innovative and absorptive capacities for competitive advantages and sustainable performances [41]. The main goal of this research was to examine the relationship and impact of knowledge management practices on sustainable entrepreneurship performance using dynamic capabilities as mediators and opportunity recognition as a moderator [42]. It has also been proven that the KSB of an entrepreneur significantly contributes to improving dynamic capacities [13]. Prior studies mostly explored this in the context of knowledge management strategies connected to DC or SEP in various industries [4], but not specifically in textile-based SMEs. A variety of textile-related SMEs, including weaving, ginning, knitting, power looms, and manual dying units, contribute significantly to the entire textile sector and economic development, particularly in developing nations. The lack of focus on this particular issue motivated the researchers to evaluate the EP of this sector through a holistic research model grounded in recourse-based theory.

Furthermore, the concept of entrepreneurial opportunity recognition (OR) observes the position, demand, and market value for a new product, and it deeply affects SEP [43,44]. Numerous researchers claimed that "an opportunity may be the chance to meet a market need through a creative combination of resources to deliver superior value" [45]. The researchers argue that opportunity means recognizing a market need with the available capabilities, which improves performance. Entrepreneurs employ opportunity sources to discover, evaluate, and exploit opportunities [46], which enhances SEP and organizational performance by increasing the capabilities of entrepreneurs [47]. This study proposes an integrated research framework ensuring the moderating role of OR to strengthen the relationship of DC and SEP in SMEs, which has not been studied yet in a similar context (as per our best knowledge). The rest of this paper is divided into several sections covering the theoretical justification, hypothesis development, methodology, results, discussion, conclusion, and study implications.

Sustainable entrepreneurship is regarded as a creative, market-oriented personality-a style of value generation that provides new start-ups using environmental management techniques or cleaner manufacturing procedures [48]. The primary aim of the current study was to develop a business venue using KSB, innovation capacity, and absorptive capacity to create sustainable entrepreneurship [49]. This research is based on knowledge sharing behaviors (KSB), innovative capability (IC), and absorptive capacity (AC) to enhance sustainable entrepreneurial performance [50], and entrepreneurial behavior results from sustainable performance [51]. In existing research, intentional models involve understanding sustainable entrepreneurial performance [52]. The primary motivation for designing the current study is that the literature on the textile sector has barely addressed the rela- 
tionship between the variables mentioned above. Achieving holistic business performance is associated with considering all aspects of sustainable development, particularly in the textile sector [53]. The primary objective of this study was to explore the relationship and impact of knowledge management practices on sustainable entrepreneurship performance through dynamic entrepreneurial capabilities.

Thus, investigating a complementary perspective would fill a research gap, and this study covers the existing gap in the literature of knowledge management practices towards sustainable performance. There have been no formal studies that examine the impact of combining the concepts of knowledge sharing behavior, innovative capacity, and absorptive capacity to achieve sustainable performance. Secondly, this study measures the sustainable entrepreneurship performance of SME entrepreneurs by using dynamic capability as a mediator because the significance of the SME sector is increasing gradually. Thirdly, most previous studies focused on other industries and examined the role of knowledge management practices in business performance [3,52]. The relevance of opportunity recognition in the relationship between dynamic capability and long-term entrepreneurial performance has also been overlooked in prior studies. As a result, we employed opportunity recognition to mediate the relationship between dynamic capability and sustainable entrepreneurship performance. This dynamic capability is well suited to a specific target market in order to improve sustainable entrepreneurial performance. Thus, this study considered opportunity recognition to be a moderating element in the association between dynamic capabilities and sustainable entrepreneurial performance.

\section{Theoretical Justification and Hypothesis Development}

The conceptual framework is based on empirical studies and fundamental theories. This study looked at the significance of antecedents in relation to [54] Schumpeter's entrepreneurship theory, which is based on entrepreneurs and SEP. The concept of entrepreneurship theory (ET) supports SEP based on organizational support and resources. Moreover, the resource-based theory presented introduced "resource-based theory", emphasized difficulties in imitating the organization's features for a greater performance and viable advantage, and concluded that AC and IC are directly linked with performance [55]. Resource-based theory is applied to analyze and deduce a company's internal assets, highlighting resources, capabilities, and capacities in a framing strategy to achieve performance stability [56,57]. OR provides an entrepreneur a chance to create a new notion for a product and SEP $[58,59]$. In addition, knowledge-based theory (KBT) indicates that if knowledge management practice is applied efficiently, it creates a unique skill that leads to better sustainable entrepreneurship performance [60]. Therefore, businesses with more robust knowledge management practices are likely to accomplish business sustainability [12,42]. Li et al. [3] stated that knowledge management processes such as sharing, acquiring, and implementing knowledge constantly improve innovation capacity, which contributes to improved sustainable entrepreneurial performance. Therefore, we also integrated the above theories to develop a holistic theoretical framework to meet the objectives of this research.

\subsection{Knowledge Sharing Behavior, Dynamic Capability, and Sustainable Entrepreneurial Performance}

The interaction of social culture and sharing and exchanging knowledge with technical skills in an organization is known as KSB [61]. KSB is always voluntary; sharing and exploring any information in the organization or with the entrepreneur cannot be forced [62]. Bartol and Srivastava [61] described KSB as spreading important information within the organization, which becomes a valuable asset for performance $[63,64]$. KSB increases the tendency to understand organizational domestic and economic challenges an entrepreneur faces in sustainable performance [63]. The employee starts sharing knowledge in an organization with the entrepreneur and believes in intrinsic benefits, monetary benefits, self-satisfaction, promotion, and social recognition in the organization [65], which 
causes a negative influence on SEP. The external information shared in an organization, through socialism or initialization, becomes significant knowledge in performance [66].

Many researchers argued that organizational performance and SEP performance move in parallel, and that entrepreneurs' DC is critical to both [67]. An entrepreneur's DC considers KSB a significant asset in the organization and a major source for enhancing dynamic entrepreneurial capabilities in achieving the maximum competitive advantage in SEP [68]. An entrepreneur's planning and DC enhance and assist in directing, acting, and decision making for competitive organizational advantages and SEP [12,69].

Hypothesis 1 (H1). KSB has a positive influence on DC.

Hypothesis 2 (H2). KSB has a positive influence on EP.

Hypothesis 3 (H3). DC mediates the relationship between KSB and SEP.

\subsection{Innovative Capacity, Dynamic Capability, and Sustainable Entrepreneurial Performance}

Villa introduced the concept of IC, which is used to examine the level of innovation and invention, including potential ideas for economic activity [70]; meanwhile, the researcher also argued that "borrowing" brings innovation rather than "invention." The combination of an entrepreneur's capabilities, power, and abilities, which create something different, is known as an innovation [71,72]. IC is directly associated with the nature of entrepreneurs, and it comes in the form of entrepreneurship [64,73]. Several studies have also observed that an entrepreneur's IC plays an important role in improving SEP [74]. When entrepreneurs face certain uncertainties, IC assists in gaining, creating, and utilizing inner qualities. IC also improves decision making power and leadership skills, serves as a financial adviser in the organization, is vigilant of organization, awareness, and allocation of better opportunities with better substitutes, and becomes more beneficial for SEP [75].

Meanwhile, researchers argued that absorbing external knowledge leads the entrepreneur towards IC and SEP [76]. Furthermore, DC enhances the IC of an entrepreneur in developing a new product for the market and SEP [77]. Therefore, it can be concluded that the DC of an entrepreneur always creates a value chain with IC and performance.

Hypothesis $4 \mathbf{( H 4 ) . ~ I C ~ h a s ~ a ~ p o s i t i v e ~ i n f l u e n c e ~ o n ~ D C . ~}$

Hypothesis $\mathbf{5}$ (H5). IC has a positive influence on EP.

Hypothesis 6 (H6). DC mediates the relationship between IC and SEP.

\subsection{Absorptive Capacity, Dynamic Capability, and Entrepreneurial Performance}

$\mathrm{AC}$ is defined as the ability to recognize and assimilate new and external knowledge, which is applied for commercial purposes [78]. The AC of an entrepreneur is to absorb innovation for change and better performance [79]. Entrepreneurial AC is to focus and absorb cognitive features in learning, evaluating, and formatting outside knowledge on a large scale for SEP [80]. Here, the researchers considered AC as a potential mechanism for SEP. Sulistyo and Siyamtinah [81] stated that AC affects assimilating and acquisition, which brings a change in EP. The role of AC supports strategic planning, and creating, absorbing, building, and utilizing available opportunities [82]. Meanwhile, identifying and configuring the core competencies of entrepreneurs through dynamic capabilities enhance SEP. Absorptive capacity potential is realized when the level of realized AC rises, and the entrepreneur can use the potential AC for SEP [83].

The DC of entrepreneurs is to adapt, abandon, reconfigure, and increase valuable resources, which help in the creation and development of new values for SEP [78], arguing three types of dynamic capabilities: possession, deployment, and upgrading capabilities, which are enhanced through wisdom, and through creating, adapting, integrating, and developing resources to obtain the maximum competitive advantages [81]. AC contributes 
to the understanding and utilization of valuable information with dynamic capabilities, in order to generate the optimal marketing strategies for long-term financial profit and SEP [84]. Prior studies explained that AC enhances the process of evaluation and adaption in SEP [85]. The combination of AC and DC has a significant influence on SEP in an organization [86]. The DC of an entrepreneur emphasizes the mechanism of IC in developing, creating, and managing, which helps entrepreneurs in performance [87]. Therefore, AC and DC are necessary to gain ideas and implications for SEP.

Hypothesis 7 (H7): AC has a positive influence on DC.

Hypothesis 8 (H8): AC has a positive influence on EP.

Hypothesis 9 (H9) : DC mediates the relationship between $A C$ and EP.

\subsection{Dynamic Capability and Sustainable Entrepreneurial Performance}

Many economists deny the role of entrepreneurs as primary, while in the real world, entrepreneurs are considered the primary decision makers [88] and rulers of the economy [89]. Entrepreneurs are recognized as the backbone for organizational and economic growth. Entrepreneurial capabilities are implemented for a sustainable business model, organizational change, and SEP [71]. According to resource-based theory, DC plays a vital role in SEP [71]. DC is to peruse and observe opportunities at the right time and place to acquire the market with business strategies, available resources, capacities, and capabilities for SEP [90]. Earlier studies suggested that the DC of entrepreneurs is the primary source for a rapid and better change in organizational culture [91].

The DC of entrepreneurs restructures and changes the organizational environment directly associated with SEP [71]. The DC of entrepreneurs is the most reliable and sound source for taking competitive advantages and plays a mediating role between entrepreneurial resources and SEP [70]. As per resource-based theory, the DC of an entrepreneur contributes to accepting, maintaining, developing, and accomplishing new challenges with opportunities in the market and SEP [92]. DC is to understand, investigate, and analyze the entrepreneurial competency level and enhance an entrepreneur's resource capacity for SEP in an organization [92].

Hypothesis 10 (H10). DC has a positive influence on SEP.

\subsection{Opportunity Recognition, Dynamic Capability, and Entrepreneurial Performance}

The concept of recognition of opportunities is closely linked to entrepreneurship. Enterprise opportunities are acknowledged by conditions in which the presentation and commercialization of new goods, services, raw materials, and arrangement practices are of maximum priority compared to the cost of production [93]. While identifying entrepreneurship as a subjective issue, an opportunity itself is an objective phenomenon identified by a given person at one time [93]. Numerous entrepreneurial opportunities are generated in developing nations because faster and more efficient countries generate many possibilities for innovative participants and often distribute these to the local market [94].

In prior research, different researchers argued that entrepreneurs are different while perceiving OR [95]. The theory of OR also proposes that entrepreneurs' cognition makes entrepreneurial processes and performance more sustainable [96]. Meanwhile, Akkaya and Üstgörül's [97] study also discussed the mediating role of OR in association with entrepreneurial performance and found it to be a critical factor in enhancing SEP. In addition, several researchers have indicated that entrepreneurs' self-made tactics are essential in the OR process [98]. This study integrated OR to test its effect on the link between DC and SEP due to the lack of research attention on this essential factor. We propose the following:

Hypothesis 11 (H11). OR has a moderating effect on the relationship between DC and SEP (an increase in OR will strengthen the relationship between DC and SEP. 


\subsection{Conceptual Framework}

Figure 1 shows the conceptual model for the studied variables, and the purpose of this study is to explore the impact of KSB, innovation, and AC on SEP. Furthermore, this study describes the role of DC as a mediator between KSB, IC, and AC with SEP. This study also explored the role of OR as a moderator between DC and SEP.

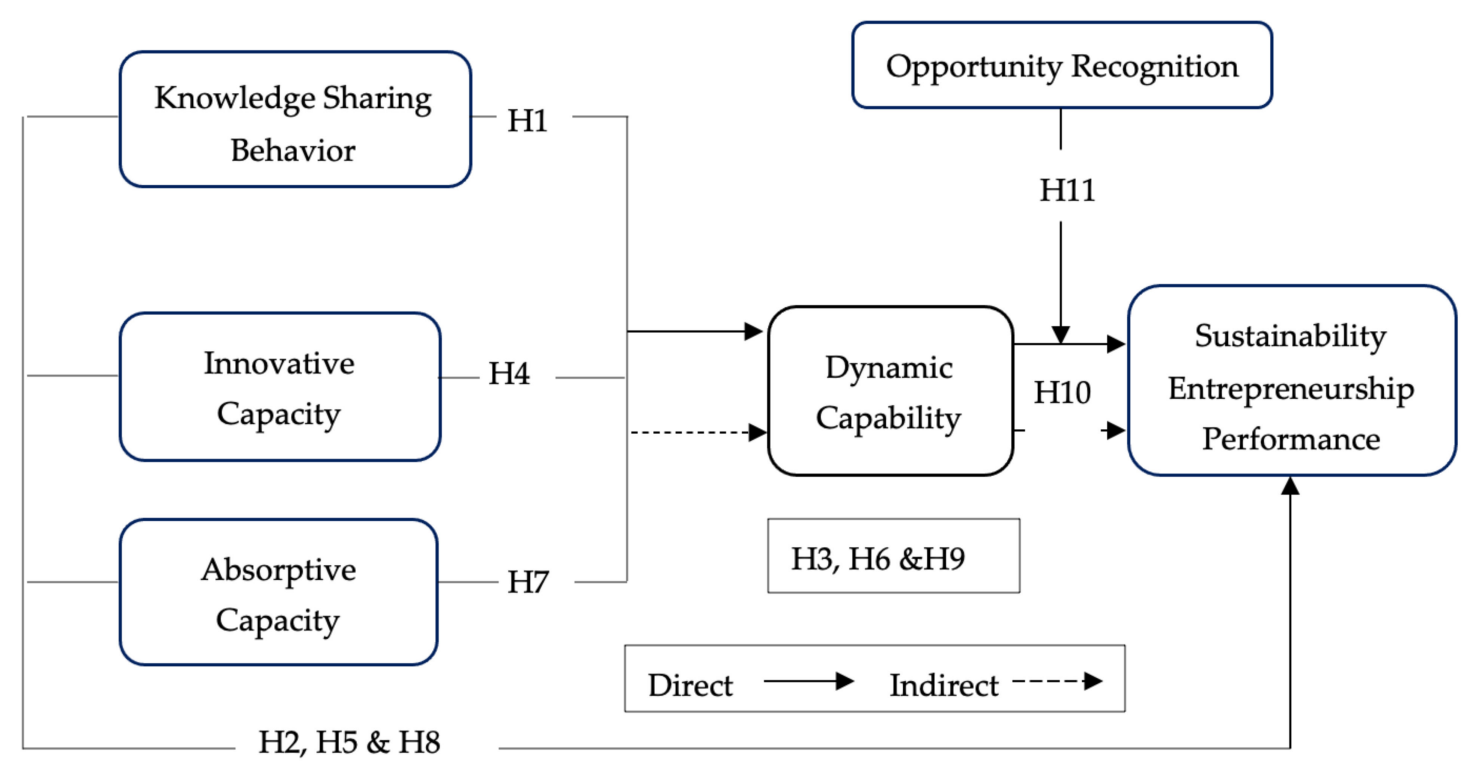

Figure 1. Research framework.

\section{Materials and Methods}

Creswell et al. [99] identified that a quantitative research technique is the best way to check the statistical relationship between variables. This study is based on a deductive method of research because it focuses on testing hypotheses arising from a current theory [100]. Therefore, we employed the survey method to test our hypotheses. We applied a cross-sectional study with a convenience sampling technique on textile-based SMEs from Kinshasa. The researcher used a time lag approach and collected data in three rounds [101]. A total of 500 digital and paper-pencil questionnaires were distributed and emailed to the target population, and 486 respondents responded fairly. There were different steps in collecting data from the respondents, and we collected data for knowledge management practices and dynamic capability measures. However, there are no significant data for registered SMEs in the chamber of commerce of Congo. Therefore, we approached respondents through emails and physically for different cities' listed SMEs [90].

Congo is also regarded as one of the least innovative countries in the textile industry. As a result, the purpose of this research is to see how highly certified firms think about KM practices in terms of achieving long-term entrepreneurial success. Because the fundamental source of knowledge is the acquisition and application of information, which leads to sustainable performance, it may help to understand the specific status of green practices and provide practical consequences to other non-certified businesses in Congo. The data for this study were collected from respondents using non-probability convenience sampling. Furthermore, they were better equipped with appropriate information and, at the same time, played an essential role in knowledge transmission among diverse departments [102] We approached middle and senior managers with formal approval and requested that they participate in data collection, as did the previous researcher. The organization as a whole is represented by these responders.

In addition, the researcher also assured the respondents that their information is confidential and that the research is purely for academic purposes. The questionnaire was initially drafted in English, but it was intended for use in French, the official language in 
Congo. Therefore, the English questionnaire was translated into French and four other national languages (Kikongo (Kituba), Lingala, Swahili, and Tshiluba) by the researchers and professional native translators, working independently to ensure consistency and to make it easier for the respondents to comprehend [101].

Moreover, we also tried to encourage some female entrepreneurs to participate; however, most refused to participate. Therefore, our sample is only based on male entrepreneurs. The partial least square (PLS)-structural equation modeling (SEM) technique analyzed the proposed research model using Smart-PLS v3. Smart-PLS is a powerful tool used to test mediation-moderation models and works with multivariate and normal distributions simultaneously $[103,104]$. Additionally, it is helpful for measuring the validity and reliability of studies.

\subsection{Demographics of Respondents}

Table 1 describes the sample statistic frequency distribution of the targeted respondents. The sample statistics include age, qualification, the business sector of an entrepreneur, and the business tenure. The results show that most of the respondents fall in the age group of $33-39$ years old $(31.48 \%)$, while $16.25 \%$ of the respondents belong to the age group $26-32$, and only $9.87 \%$ are mostly young entrepreneurs below 25 years. A total of $17.9 \%$ of the respondents are $40-46$, and the remaining $24.48 \%$ are senior entrepreneurs above 47 years. Most of the respondents are highly qualified, and only $25.92 \%$ have attained a middle school certificate. During the data collection phase, we discovered that most senior entrepreneurs do not have higher education and yet are running a successful enterprise. This may be due to their leadership abilities, financial support, or many other reasons. The textile industry in Kinshasa consists of several sub-units such as knitting, weaving, seizing, power looms, and manual drying units. Therefore, we considered all these units for data collection, and the percentages are presented in Table 1. Furthermore, a question related to their experience is also described in the same table.

Table 1. The sample statistics of the respondents.

\begin{tabular}{|c|c|c|c|}
\hline Particulars & Description & Frequency & Percentage \\
\hline Gender & Male & 486 & $100 \%$ \\
\hline \multirow{5}{*}{ Age } & $18-25$ & 48 & $9.87 \%$ \\
\hline & $26-32$ & 79 & $16.25 \%$ \\
\hline & $33-39$ & 153 & $31.48 \%$ \\
\hline & $40-46$ & 87 & $17.90 \%$ \\
\hline & 47 Above & 119 & $24.48 \%$ \\
\hline \multirow{5}{*}{ Educational Qualification } & Middle School & 126 & $25.92 \%$ \\
\hline & High School & 159 & $32.71 \%$ \\
\hline & Graduation Level & 117 & $24.07 \%$ \\
\hline & University Level & 67 & $13.78 \%$ \\
\hline & $\begin{array}{c}\text { Professional } \\
\text { Education }\end{array}$ & 17 & $3.49 \%$ \\
\hline \multirow{5}{*}{ Business Sector } & Knitting & 147 & $30.25 \%$ \\
\hline & Weaving & 84 & $17.28 \%$ \\
\hline & Seizing & 79 & $16.26 \%$ \\
\hline & Power Looms & 93 & $19.14 \%$ \\
\hline & $\begin{array}{c}\text { Manual Drying } \\
\text { Units }\end{array}$ & 83 & $17.08 \%$ \\
\hline \multirow{6}{*}{ Business Tenure } & $1-5$ years & 74 & $15.22 \%$ \\
\hline & $6-10$ years & 127 & $26.13 \%$ \\
\hline & $11-15$ years & 126 & $25.92 \%$ \\
\hline & $16-20$ years & 87 & $17.90 \%$ \\
\hline & $21-25$ years & 34 & $6.99 \%$ \\
\hline & 25 years above & 38 & $7.81 \%$ \\
\hline
\end{tabular}




\subsection{The Measures}

A structured questionnaire was developed to ensure that the content of the research model was practical and realistic. All variables were constructed and operationalized using the existing literature on sustainable entrepreneurial performance, knowledge sharing capacity, absorptive capacity, dynamic capability, innovative capacity, and opportunity recognition. A 5-point Likert scale ranging from 1 (strongly disagree) to 5 (strongly agree) was employed to measure all constructs. Five items were adapted from the study by Hsu [105] to assess information sharing abilities. We used five measuring constructs from Hurley's [106] study to evaluate inventive capability as an exemplary item, "I frequently participate in knowledge sharing activities." To test absorptive capacity, four items were used [107]. A representative item was "risk-taking is encouraged in our firm." The item "our firm regularly considers the consequences of changing market demand in terms of new ways to provide services" was used to test the dynamic capability measured using two dimensions: exploration and exploitation, with three items each. This scale was adapted from the study by $[108,109]$.

\subsection{Measurement Model}

Table 2 shows the results of the convergent validity and reliability analysis of the data collected from the respondents. To confirm the convergent validity, we used Smart-PLS3 to conduct confirmatory factor analysis (CFA), composite reliability (CR), and average variance extracted (AVE). Cronbach's alpha values were also checked to ensure reliability. The overall values of Cronbach's alpha range from 0.936 to 0.953 , which is higher than the threshold value, according to Table 2. The levels of CR and AVE are also higher than the prescribed values, validating the study's reliability and convergent validity $[104,110]$. This study also looked at discriminant validity, which is the degree to which components differ experimentally from one another [111]. The criterion for discriminant validity analysis is shown in Table 3. The results suggest that discriminant validity is not a problem because the diagonal values (square root of AVE) are higher than the inter-construct correlations, as advised by [112].

Table 2. Convergent validity and reliability.

\begin{tabular}{|c|c|c|c|c|c|}
\hline Constructs & & Factor Loading & Alpha & CR & AVE \\
\hline \multirow{5}{*}{$\begin{array}{c}\text { KNOWLEDGE SHARING } \\
\text { BEHAVIOR }\end{array}$} & KSB1 & 0.942 & \multirow{5}{*}{0.953} & \multirow{5}{*}{0.953} & \multirow{5}{*}{0.804} \\
\hline & KSB2 & 0.914 & & & \\
\hline & KSB3 & 0.899 & & & \\
\hline & KSB4 & 0.804 & & & \\
\hline & KSB5 & 0.917 & & & \\
\hline \multirow{5}{*}{ INNOVATIVE CAPACITY } & IC1 & 0.922 & \multirow{5}{*}{0.936} & \multirow{5}{*}{0.935} & \multirow{5}{*}{0.743} \\
\hline & IC2 & 0.872 & & & \\
\hline & IC3 & 0.852 & & & \\
\hline & IC4 & 0.866 & & & \\
\hline & IC5 & 0.793 & & & \\
\hline \multirow{4}{*}{ ABSORPTIVE CAPACITY } & $\mathrm{AC} 1$ & 0.965 & \multirow{4}{*}{0.936} & \multirow{4}{*}{0.936} & \multirow{4}{*}{0.785} \\
\hline & $\mathrm{AC} 2$ & 0.826 & & & \\
\hline & AC3 & 0.855 & & & \\
\hline & $\mathrm{AC} 4$ & 0.893 & & & \\
\hline \multirow{5}{*}{ DYNAMIC CAPABILITY } & DC1 & 0.822 & \multirow{5}{*}{0.945} & \multirow{5}{*}{0.946} & \multirow{5}{*}{0.746} \\
\hline & DC2 & 0.759 & & & \\
\hline & DC3 & 0.900 & & & \\
\hline & DC4 & 0.915 & & & \\
\hline & DC5 & 0.880 & & & \\
\hline
\end{tabular}


Table 2. Cont.

\begin{tabular}{cccccc}
\hline Constructs & & Factor Loading & Alpha & CR & AVE \\
\hline & OR1 & 0.774 & & & \\
OPPORTUNITY & OR2 & 0.902 & & & \\
RECOGNITION & OR3 & 0.929 & 0.942 & 0.940 & 0.725 \\
& OR4 & 0.897 & & & \\
& OR5 & 0.819 & & \\
& OR6 & 0.773 & & \\
ENTREPRENEURIAL & EP1 & 0.726 & & \\
PERFORMANCE & EP2 & 0.765 & & \\
& EP3 & 0.825 & & \\
& EP4 & 0.812 & & \\
& EP5 & 0.812 & & \\
& EP6 & 0.955 & 0.950 & & \\
& EP7 & 0.786 & & & \\
& EP8 & 0.768 & & & \\
& EP9 & 0.747 & & & \\
& EP10 & 0.767 & & & \\
& EP11 & 0.747 & & & \\
& & &
\end{tabular}

Table 3. Fornell-Lacker criterion discriminant validity.

\begin{tabular}{ccccccc}
\hline & AC & DC & SEP & IC & KSB & OR \\
\hline AC & 0.886 & & & & & \\
DC & 0.427 & 0.864 & & & & \\
SEP & 0.435 & 0.415 & 0.794 & & & \\
IC & 0.339 & 0.371 & 0.447 & 0.862 & & \\
KSB & 0.553 & 0.427 & 0.453 & 0.453 & 0.897 & \\
OR & 0.237 & 0.366 & 0.379 & 0.186 & 0.247 & 0.851 \\
\hline
\end{tabular}

Note: Diagonal values are the square root of the average variance extracted from each construct.

Furthermore, heterotrait-monotrait ratio (HTMT) analysis for discriminant validity was also applied [113]. A value of the HTMT ratio closer to one indicates a lack of discriminant validity in the path analysis [112]. To clearly distinguish the two factors, the HTMT ratio should be less than one [112]. The current study results shown in Table 4 show that the values are in accordance with the threshold values. Therefore, we can conclude that there is no issue of discriminant validity at all.

Table 4. Heterotrait-monotrait (HTMT) ratios.

\begin{tabular}{cccccc}
\hline & AC & DC & EP & IC & KSB \\
\hline DC & 0.428 & & & & \\
SEP & 0.432 & 0.410 & & & \\
IC & 0.337 & 0.370 & 0.446 & & \\
KSB & 0.551 & 0.427 & 0.453 & 0.450 & \\
OR & 0.233 & 0.366 & 0.378 & 0.186 & 0.245 \\
\hline
\end{tabular}

\subsection{Structural Model}

To test the hypotheses, we applied PLS-SEM in the current study. Figure 2 shows the results of the path analysis, which are also described in Table 5 . The value of the adjusted $\mathrm{R}$-square of the dependent variable is 0.402 , showing that these selected variables explain a total of $40 \%$ of the variation. Nevertheless, this study considered DC as a mediator, showing a $26.5 \%$ variation. The consistent bootstrapping test was applied for confirming the significance of the structural model [97]. 


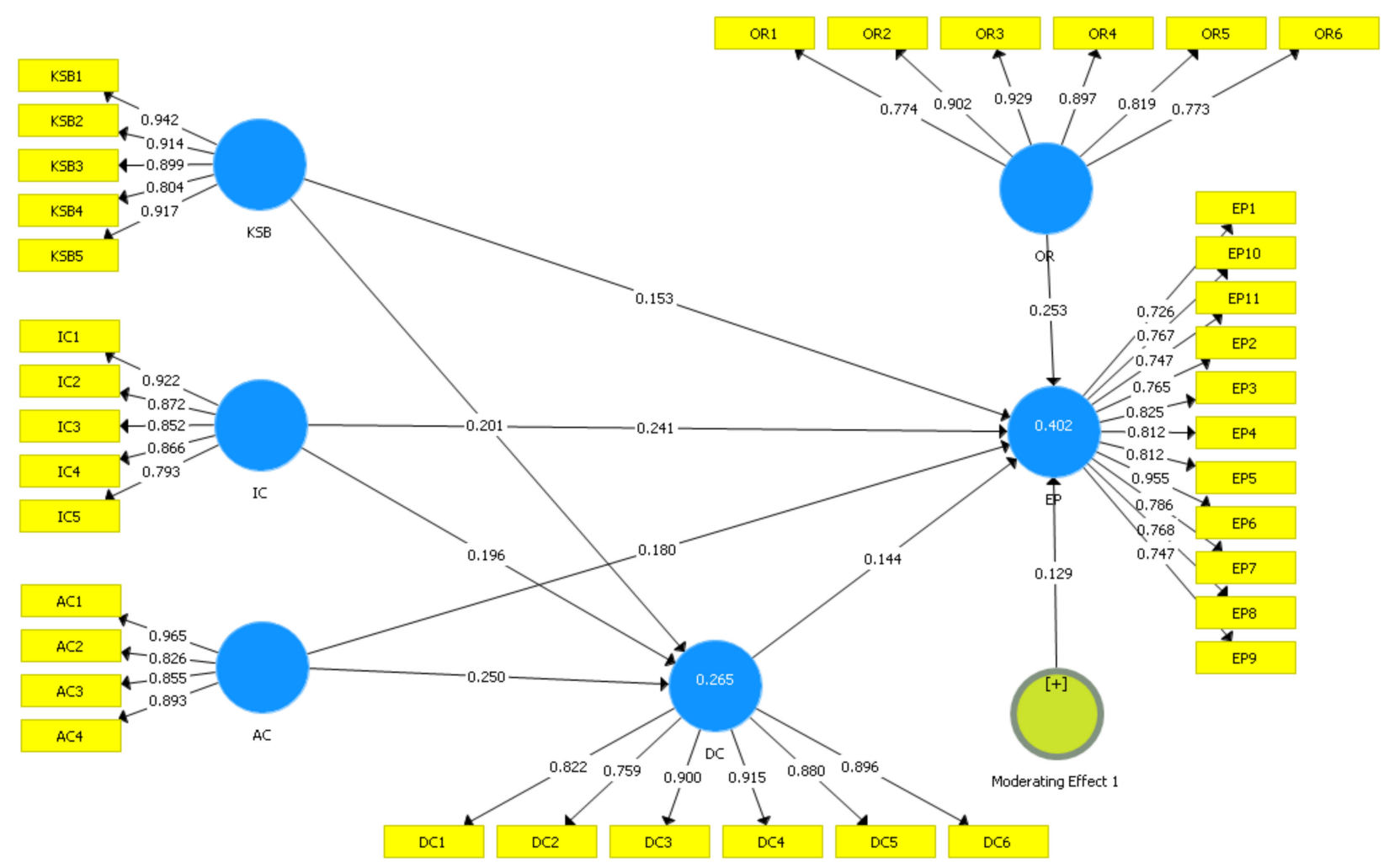

Figure 2. Results of path analysis.

Table 5. SEM results with bootstrapping (total direct effect).

\begin{tabular}{ccccccc}
\hline Hypothesis & Relationship & $\boldsymbol{\beta}$ & S.D & $\boldsymbol{t}$-Values & $\boldsymbol{p}$-Values & Decision \\
\hline H1 & KSB $\rightarrow$ DC & 0.201 & 0.048 & 4.194 & 0.000 & Supported \\
H2 & KSB $\rightarrow$ SEP & 0.153 & 0.060 & 2.541 & 0.011 & Supported \\
H4 & IC $\rightarrow$ DC & 0.196 & 0.045 & 4.378 & 0.000 & Supported \\
H5 & IC $\rightarrow$ EP & 0.241 & 0.049 & 4.925 & 0.000 & Supported \\
H7 & AC $\rightarrow$ DC & 0.250 & 0.053 & 4.696 & 0.000 & Supported \\
H8 & AC $\rightarrow$ SEP & 0.180 & 0.054 & 3.339 & 0.001 & Supported \\
H10 & DC $\rightarrow$ SEP & 0.144 & 0.051 & 2.814 & 0.005 & Supported \\
\hline
\end{tabular}

According to the results of Table 5, H1 showed a direct positive effect of KSB on DC, and therefore $\mathrm{H} 1$ is supported $(\beta=0.201 ; t=4.194 ; p<0.000)$ with the direct positive and significant relationship between KSB and DC. $\mathrm{H} 2$ demonstrated a direct positive effect of KSB on SEP, and therefore H2 is supported $(\beta=0.153 ; t=2.541 ; p<0.011)$, indicating that KSB has a positive and significant impact on SEP. H4 explained a direct positive effect of IC on DC, and therefore H4 is supported $(\beta=0.196 ; t=4.378 ; p<0.000)$, indicating that IC has a positive and significant effect on DC. Meanwhile, $\mathrm{H} 5$ also showed a direct and positive effect of IC on EP, and therefore H5 is supported $(\beta=0.241 ; t=4.925 ; p<0.000)$, indicating that IC has a positive and significant effect on EP. H7 also explored a direct positive effect of AC on DC, and therefore H7 is supported $(\beta=0.250 ; t=4.696 ; p<0.000)$, indicating that $\mathrm{AC}$ has a direct and significant effect on DC. At the same time, $\mathrm{H} 8$ also showed a direct positive effect of AC on SEP; therefore, H8 is supported $(\beta=0.180 ; t=3.339 ; p<0.001)$, showing a positive and significant effect between AC and SEP. The last direct effect of H10 showed a positive direction of DC on SEP; therefore, H10 is supported $(\beta=0.144 ; t=2.814$; $p<0.005)$, showing that DC has a positive and significant impact on SEP.

Table 6 shows the indirect effects of KSB, IC, and AC on sustainable entrepreneurial performance through DC and the moderating effect of OR on the relationship between DC and SEP. This study also measured the mediating and moderating role of DC and 
OR. Table 6 represents the values of the SEM results for the specific indirect effects. The results for $\mathrm{H} 3$ confirm that DC mediates the relationship between KSB and SEP; therefore, H3 $(\beta=0.029 ; t=2.204 ; p<0.028)$ is supported, showing that there is partial mediation between KSB and SEP through DC. H6 showed that DC mediates the relationship between IC and SEP; therefore, H6 is supported with values of $(\beta=0.028 ; t=2.270 ; p<0.023)$, showing partial mediation between IC and SEP.

Table 6. SEM results with bootstrapping (specific indirect effect).

\begin{tabular}{ccccccc}
\hline Hypotheses & Constructs & $\boldsymbol{\beta}$ & (SD) & $\boldsymbol{t}$-Values & $\boldsymbol{p}$-Values & Decision \\
\hline H3 & KSB $\rightarrow$ DC $\rightarrow$ SEP & 0.029 & 0.013 & 2.204 & 0.028 & Partially mediates \\
H6 & IC $\rightarrow$ DC $\rightarrow$ SEP & 0.028 & 0.012 & 2.270 & 0.023 & Partially mediates \\
H9 & AC $\rightarrow$ DC $\rightarrow$ SEP & 0.036 & 0.015 & 2.395 & 0.017 & Partially mediates \\
H11 & ORxDC $\rightarrow$ SEP & 0.129 & 0.030 & 4.269 & 0.000 & Moderation proved \\
\hline
\end{tabular}

Meanwhile, H9 confirms that DC mediates the relationship between AC and SEP; therefore, $\mathrm{H} 3(\beta=0.036 ; t=2.395 ; p<0.017)$ is supported, showing partial mediation between AC and SEP through DC. Moreover, this study considers the moderating effect of OR on the relationship between the DC and SEP of textile-based SMEs in Kinshasa, Congo. The results are presented in Table 6, showing that OR significantly and positively moderates the relationship between DC and SEP $(\beta=0.129 ; t=4.269 ; p<0.000)$. Figure 3 represents the moderation effect of OR on SEP, showing that OR significantly strengthened the positive relationship of DC and SEP.

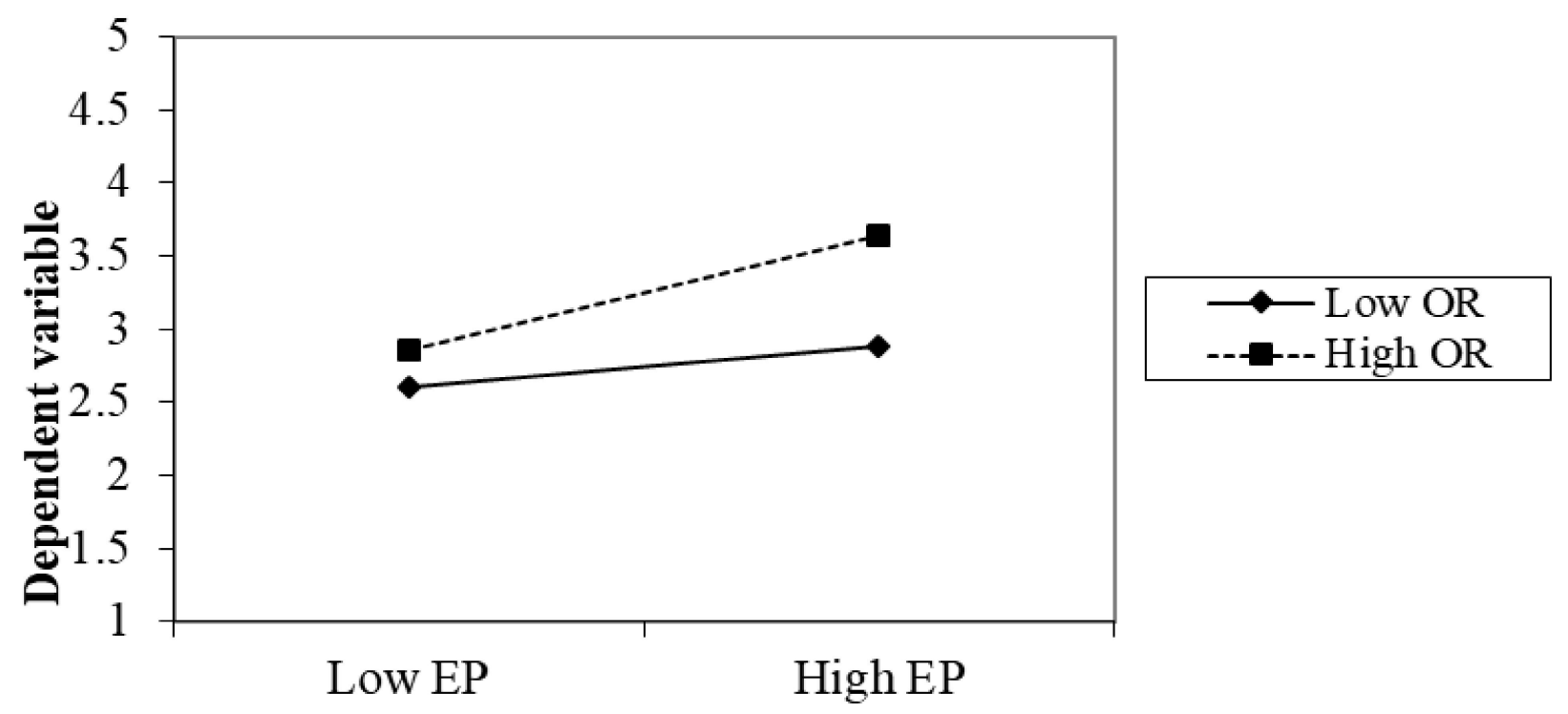

Figure 3. Moderation result.

\section{Discussion}

This research explored the impact of knowledge management practices on sustainable entrepreneurship performance, with mediating and moderating effects of dynamic capabilities and opportunity recognition. The path coefficient supports the provided hypotheses empirically and identifies significant findings with $p$-value $<0.05$ and $t$-value $>2$.

Based on the overall statistical results of our study, $\mathrm{H} 1$ for knowledge sharing behavior provides a significant effect on DC, which is in line with [114]. This means that KSB can spread important information within the organization, which becomes a valuable asset for sustainable performance $[107,115]$. KSB can increase the tendency to understand the organizational domestic and economic challenges an entrepreneur faces in sustainable performance. Knowledge sharing behavior demonstrates the effect of dynamic capabilities, which help to determine, integrate, and reconfigure internal and external capabilities for 
better sustainable performance. The result of $\mathrm{H} 2$ shows that knowledge sharing behavior has a good association with sustainable entrepreneurship performance. The findings are also consistent with those of earlier investigations by [116]. H3 showed an indirect effect of dynamic capabilities on the relationship between knowledge sharing behavior and sustainable entrepreneurial performance. Knowledge sharing behavior enhances the sustainable entrepreneurial performance through an indirect relation with dynamic capabilities. This finding is similar to that of previous studies by [105].

The finding of $\mathrm{H} 4$ suggests that innovative capacity influences dynamic capabilities, and this conclusion is similar to that of previous investigations [114]. The conclusion of H5 shows that the effect of innovative capacity on sustainable entrepreneurial performance is favorable, and the findings are similar to those of a previous study by Jantunen et al. [116]. The results of $\mathrm{H} 6$ suggest that innovative capacity positively influences sustainable entrepreneurial performance through dynamic capabilities, which is linked to Furman's [102] previous study. When entrepreneurs face adversity, innovative capacity contributes to acquiring, creating, and applying inner values. Innovative capacity boosts decision making power and leadership abilities, assists as a financial adviser in the organization, is attentive to organization, awareness, and allocation of better opportunities with better substitutes, and benefits sustainable entrepreneurial performance [75]. Furthermore, H6 confirms that dynamic capacity positively mediates the association between innovative capacity and sustainable entrepreneurial performance. These results are consistent with those of previous studies by [42].

Additionally, the study of $\mathrm{H7}$ revealed that absorptive capacity has positive influences on dynamic capabilities, and these findings are consistent with those of previous research [117]. Dynamic capability reorganizes and modifies the organizational environment which is closely linked to sustainable entrepreneurial performance [71]. Dynamic capability is the most dependable and sound source for gaining competitive advantages, and it acts as a link between entrepreneurial resources and SEP $[13,70]$. Nonetheless, H8 claims that absorption capacity positively impacts long-term entrepreneurship success, and the findings are linked to those of [31]. According to H9, dynamic capability favorably and significantly mediates between absorptive capacity and sustainable entrepreneurial performance $[105,118]$.

The H10 dynamic capabilities positively impact sustainable entrepreneurial performance $[119,120]$. Finally, H11's findings reveal that opportunity recognition moderates the relationship between dynamic capacity and sustainable entrepreneurial performance. The data show a significant and favorable moderation effect on the relationship between dynamic talents and sustainable entrepreneurial success [121]. Several studies have found that self-made approaches used by entrepreneurs are critical in the opportunity recognition process [85]. Because there has been less research on the link between DC and SEP, this study combined OR to see how it affects the link.

\section{Implications}

This study contributes to the growing body of knowledge about SME performance, dynamic capabilities, potential opportunities, and knowledge management capabilities. The results of the research mentioned above help lower the failure rate of firms, which is better understood by the government and non-government textile sectors. Secondly, this study reveals that textile-based SMEs with a low performance can benefit significantly from this study's findings. Furthermore, this research aids SMEs in developing more effective methods of knowledge transfer to foster a strong organizational climate that can better compete against competitors. The lack of internal and external information that the SME faces can impact the company's long-term performance. Using the dynamic capacities of the organization, SMEs can also develop their organizational and entrepreneurial potential. Furthermore, this research has broader implications for an industrial practitioner in the field of small-medium performance toward substantial firm and entrepreneurial performance. 


\section{Conclusions}

This study extends the existing literature by exploring the importance of knowledge management practices with sustainable entrepreneurship performance, opportunity recognition, and dynamic capabilities of textile-based SMEs. Several studies have looked at how knowledge management techniques affect SME sustainability, but little attention has been paid to dynamic capabilities' vital role. As a result, the impact of opportunity recognition and SMEs' dynamic capabilities connected to knowledge management methods on sustainable entrepreneurship performance is important.

This study's findings indicate that knowledge management methods had a considerable impact on SME entrepreneurial performance, as evidenced by the significant beta coefficient, $t$-values, and $p$-values. Furthermore, the findings reveal that dynamic capabilities are critical to SME performance and that opportunity recognition moderates the relationship between dynamic capabilities and entrepreneurial performance. These arguments show how knowledge management strategies help entrepreneurs perform better, which impacts unemployment and economic growth. In addition, other industries have underlined the need to understand existing attitudes toward green products. As a result, the textile sector should look at these rapidly growing consumer content strategies. Textile management teams must fulfill the demands of increasing customer satisfaction and loyalty. As a result, research into this new type of textile consumer is needed.

\section{Limitations and Future Research}

The present study has limitations concerning the data source and sampling, which affect the internal and external validity of the study. The data consist of a single source. This research used cross-sectional data; however, longitudinal data should be used in the future. This approach would improve the study in order to promote the success of Congo's SME industries. To obtain a higher performance in SMEs, a detailed and better conclusion for the research could include government policies and demographics as a control variable. Another limitation of this research is that, due to the chosen region, the sample population was confined to males. Gender biases may have influenced the findings of this study. Any future study should take both males and females into account.

Lastly, this study focused on male entrepreneurs in the Congolese textile industry. However, to be more inclusive, the study may include additional and different industries, such as enterprises with more male and female entrepreneurs. Furthermore, future research can be conducted on a similar pattern in a different time zone. It has also been stated that knowledge and innovation capacities are not constant, which may be enhanced with the situation developed. Hence, people can vary in their knowledge and learning abilities throughout time. Future researchers should undertake a longitudinal study on the spectrum that is outlined in this research.

Author Contributions: Conceptualization, S.M.T. and N.W.; methodology, S.M.T. and M.N.; validation, N.W. and S.M.T.; formal analysis, M.N.; investigation, S.M.T.; resources, N.W.; data curation, S.M.T.; writing original draft preparation, S.M.T.; writing review and editing, S.F.A. and N.S.; visualization, S.M.T.; supervision, N.W.; project administration, N.W. and S.M.T.; funding acquisition, N.W. All authors have read and agreed to the published version of the manuscript.

Funding: This research was funded by The National Natural Science Foundation of China, grant numbers 71971101 and 71972090, and the key project of philosophy and social science research in colleges and universities of Jiangsu Province, grant number 2019SJZDA032.

Institutional Review Board Statement: Not Applicable.

Informed Consent Statement: Not Applicable.

Data Availability Statement: The datasets used in this study are available in the text and cited in the Reference section.

Acknowledgments: We are grateful to Vivian Andoh for her immense support to this paper. 
Conflicts of Interest: The authors declare that the research was conducted in the absence of any commercial or financial relationships that could be constructed as a potential conflict of interest.

\section{Abbreviations \\ Knowledge sharing behavior (KSB)}

Innovation capacity (IC)

Absorptive capacities (AC)

Dynamic capabilities (DC)

Opportunity recognition (OR)

Sustainability entrepreneurship performance (SEP)
KS behavior is defined as "a set of individual behaviors involving sharing one's work-related knowledge and expertise with other members within one's organization" [15].

Innovation capacity is defined as continually improving firms' capabilities and resources to discover opportunities to develop new products $[4,15]$.

The ability of firms to recognize, assimilate and apply new knowledge for the benefit of their business performance [41].

Dynamic capabilities are defined as "the firm's ability to integrate, build, and reconfigure internal and external competencies to address rapidly changing environments" [42].

Opportunity recognition (OR) is how entrepreneurs identify potential ways to identify new business based on their opportunities. Opportunity recognition (OR) is how entrepreneurs identify potential ways towards identifying new businesses based on the opportunities they identify [43,44].

Sustainable performance of an organization refers to its ability to meet the needs and expectations of customers and other stakeholders in the long-term, balanced by an effective management organization by organization staff awareness by learning and applying appropriate improvements and innovation [20].

\section{References}

1. Middermann, L.H.; Kratzer, J.; Perner, S. The impact of environmental risk exposure on the determinants of sustainable entrepreneurship. Sustainability 2020, 12, 1534. [CrossRef]

2. Abubakar, A.M.; Elrehail, H.; Alatailat, M.A.; Elçi, A. Knowledge management, decision-making style and organizational performance. J. Innov. Knowl. 2019, 4, 104-114. [CrossRef]

3. Li, C.; Ashraf, S.F.; Shahzad, F.; Bashir, I.; Murad, M.; Syed, N.; Riaz, M. Influence of knowledge management practices on entrepreneurial and organizational performance: A mediated-moderation model. Front. Psychol. 2020, 11, 2862. [CrossRef]

4. Makhloufi, L.; Laghouag, A.; Sahli, A.A.; Belaid, F. Impact of entrepreneurial orientation on innovation capability: The mediating role of absorptive capability and organizational learning capabilities. Sustainability 2021, 13, 5399. [CrossRef]

5. Antunes, H.D.J.G.; Pinheiro, P.G. Linking knowledge management, organizational learning and memory. J. Innov. Know. 2020, 5, 140-149. [CrossRef]

6. Cerchione, R.; Esposito, E. A systematic review of supply chain knowledge management research: State of the art and research opportunities. Int. J. Prod. Econ. 2016, 182, 276-292. [CrossRef]

7. Zheng, Y.; Han, W.; Yang, R. Does government behaviour or enterprise investment improve regional innovation performanceEvidence from China. Int. J. Technol. Manag. 2021, 85, 274. [CrossRef]

8. Lotfi, M.; Yousefi, A.; Jafari, S. The effect of emerging green market on green entrepreneurship and sustainable development in knowledge-based companies. Sustainability 2018, 10, 2308. [CrossRef]

9. Schaltegger, S.; Wagner, M. Sustainable entrepreneurship and sustainability innovation: Categories and interactions. Bus. Strat. Environ. 2011, 20, 222-237. [CrossRef] 
10. Martins, V.; Rampasso, I.; Anholon, R.; Quelhas, O.; Filho, W.L. Knowledge management in the context of sustainability: Literature review and opportunities for future research. J. Clean. Prod. 2019, 229, 489-500. [CrossRef]

11. Vickers, N.J. Animal communication: When i'm calling you, will you answer too? Curr. Biol. 2017, 27, R713-R7152017. [CrossRef]

12. Lüdeke-Freund, F. Sustainable entrepreneurship, innovation, and business models: Integrative framework and propositions for future research. Bus. Strat. Environ. 2020, 29, 665-681. [CrossRef]

13. Pai, F.-Y.; Chang, H.-F. The effects of knowledge sharing and absorption on organizational innovation performance-A dynamic capabilities perspective. Interdiscip. J. Info. Know. Manag. 2013, 8, 083-097. [CrossRef]

14. Liu, S.M.; Hu, R.; Kang, T.W. The effects of absorptive capability and innovative culture on innovation performance: Evidence from Chinese high-tech firms. J. Asian Financ. Eco. Bus. 2021, 8, 1153-1162.

15. Kurniawan, P.; Hartati, W.; Qodriah, S.L.; Badawi, B. From knowledge sharing to quality performance: The role of absorptive capacity, ambidexterity and innovation capability in creative industry. Manag. Sci. Lett. 2020, 433-442. [CrossRef]

16. Chang, D.L.; Marques, J.S.; Da Costa, E.M.; Selig, P.M.; Yigitcanlar, T. Knowledge-based, smart and sustainable cities: A provocation for a conceptual framework. J. Open Innov. Technol. Mark. Complex. 2018, 4, 1-17. [CrossRef]

17. Van Reijsen, J.; Helms, R.; Batenburg, R.; Foorthuis, R. The impact of knowledge management and social capital on dynamic capability in organizations. Know. Manag. Res. Pract. 2009, 13, 401-417. [CrossRef]

18. Mohamed, M.; Stankosky, M.; Mohamed, M. An empirical assessment of knowledge management criticality for sustainable development. J. Know. Manag. 2009, 13, 271-286. [CrossRef]

19. Bucci, M.; El-Diraby, T.E. The functions of knowledge management processes in urban impact assessment: The case of Ontario. Impact Asses. Proj. Apprais. 2018, 36, 265-280. [CrossRef]

20. Youssef, A.B.; Boubaker, S.; Omri, A. Entrepreneurship and sustainability: The need for innovative and institutional solutions. Technol. Forecast. Soc. Chang. 2018, 129, 232-241.

21. Acs, Z.J.; Estrin, S.; Mickiewicz, T.; Szerb, L. Entrepreneurship, institutional economics, and economic growth: An ecosystem perspective. Small Bus. Econ. 2018, 51, 501-514. [CrossRef]

22. De Clercq, D.; Honig, B.; Martin, B. The roles of learning orientation and passion for work in the formation of entrepreneurial intention. Int. Small Bus. J. Res. Entrep. 2012, 31, 652-676. [CrossRef]

23. González-Serrano, M.H.; Sanz, V.A.; González-García, R.J. Sustainable sport entrepreneurship and innovation: A bibliometric analysis of this emerging field of research. Sustainability 2020, 12, 5209. [CrossRef]

24. Terán-Yépez, E.; Marín-Carrillo, G.M.; Casado-Belmonte, M.D.P.; Capobianco-Uriarte, M.D.L.M. Sustainable entrepreneurship: Review of its evolution and new trends. J. Clean. Prod. 2019, 252, 119742. [CrossRef]

25. Shane, S.; Locke, E.A.; Collins, C.J. Entrepreneurial motivation. Hum. Resour. Manag. Rev. 2003, 13, 257-279. [CrossRef]

26. Veronica, S.; Manlio, d.G.; Shlomo, T.; Antonio, M.P.; Victor, C. International social SMEs in emerging countries: Do governments support their international growth? J. World Bus. 2019, 55, 100995. [CrossRef]

27. Urban, B.; Kongo, M. The relevance of human capital to firm performance: A focus on the retail industry in Kinshasa, Democratic Republic of Congo. Acta Commer. 2015, 15, 1-9. [CrossRef]

28. Ngassa, T.C. The influence of entrepreneurship training on profit gaps amongst young male and female entrepreneurs in congo. Mod. Econ. 2021, 12, 1092-1104. [CrossRef]

29. Awan, U.; Khattak, A.; Rabbani, S.; Dhir, A. Buyer-driven knowledge transfer activities to enhance organizational sustainability of suppliers. Sustainability 2020, 12, 2993. [CrossRef]

30. Hasan, F.S.; Almubarak, M.M.S. Factors influencing women entrepreneurs' performance in SMEs. World J. Entrep. Manag. Sustain. Develop. 2016, 12. [CrossRef]

31. Gebauer, H.; Worch, H.; Truffer, B. Absorptive capacity, learning processes and combinative capabilities as determinants of strategic innovation. Eur. Manag. J. 2012, 30, 57-73. [CrossRef]

32. Al-Husseini, S.; Elbeltagi, I. Evaluating the effect of transformational leadership on knowledge sharing using structural equation modelling: The case of Iraqi higher education. Int. J. Leader. Educ. 2018, 21, 506-517. [CrossRef]

33. Azaizah, N.; Reychav, I.; Raban, D.R.; Simon, T.; McHaney, R. Impact of ESN implementation on communication and knowledgesharing in a multi-national organization. Int. J. Inf. Manag. 2018, 43, 284-294. [CrossRef]

34. Shao, Z.; Feng, Y.; Liu, L. The mediating effect of organizational culture and knowledge sharing on transformational leadership and Enterprise Resource Planning systems success: An empirical study in China. Comput. Hum. Behav. 2012, 28, $2400-2413$. [CrossRef]

35. Vargas, N.; Lloria, M.B.; Salazar, A.; Vergara, L. Effect of exploitation and exploration on the innovative as outcomes in entrepreneurial firms. Int. Entrep. Manag. J. 2018, 14, 1053-1069. [CrossRef]

36. Rahmani, B.; Morid, S.P.; Shahed, S.H. Tourism capacity in the development of sustainable entrepreneurship in rural areas (Case Study: Central District of Hamadan). J. Urban. Manag. 2018, 17, 65-97.

37. Hakuzimanaa, J.; Masasib, B. Performance evaluation of irrigation schemes in Rugeramigozi marshland, Rwanda. Water Conserv. Manag. 2020, 4, 15-19. [CrossRef]

38. Lane, P.; Salk, J.; Lyles, M.J.S.M.J. Knowledge acquisition and performance in transitional economy international joint ventures. Strateg. Manag. J. 2001, 22, 97-102.

39. Feng, T.; Cai, D.; Wang, D.; Zhang, X. Environmental management systems and financial performance: The joint effect of switching cost and competitive intensity. J. Clean. Prod. 2016, 113, 781-791. [CrossRef] 
40. Revuelto-Taboada, L.; Simón-Moya, V. A comprehensive understanding of social and sustainable entrepreneurship. Manag. Decis. 2012, 50, 744-748.

41. Giniuniene, J.; Jurksiene, L. Dynamic capabilities, innovation and organizational learning: Interrelations and impact on firm performance. Procedia Soc. Behav. Sci. 2015, 213, 985-991. [CrossRef]

42. Protogerou, A.; Caloghirou, Y.; Lioukas, S. Dynamic capabilities and their indirect impact on firm performance. Ind. Corp. Chang. 2011, 21, 615-647. [CrossRef]

43. Jiang, W.; Chai, H.; Shao, J.; Feng, T. Green entrepreneurial orientation for enhancing firm performance: A dynamic capability perspective. J. Clean. Prod. 2018, 198, 1311-1323. [CrossRef]

44. Cohen, B.; Winn, M.I. Market imperfections, opportunity and sustainable entrepreneurship. J. Bus. Vent. 2007, 22, 29-49. [CrossRef]

45. Clark, K.; Ramachandran, I. Subsidiary entrepreneurship and entrepreneurial opportunity: An institutional perspective. J. Int. Manag. 2019, 25, 37-50. [CrossRef]

46. Chung, L.H.; Gibbons, P.T. Management, Corporate entrepreneurship: The roles of ideology and social capital. Group Organ. Manag. 1997, 22, 10-30. [CrossRef]

47. Yi, G. From green entrepreneurial intentions to green entrepreneurial behaviors: The role of university entrepreneurial support and external institutional support. Int. Entrepreneur. Manag. J. 2021, 17, 963-979. [CrossRef]

48. Kloepfer, K.; Castrogiovanni, G.J. Entrepreneurship: Venture creation subprocesses, subdomains, and interfaces. Int. Entrep. Manag. J. 2018, 14, 681-696. [CrossRef]

49. Gast, J.; Gundolf, K.; Cesinger, B. Doing business in a green way: A systematic review of the ecological sustainability entrepreneurship literature and future research directions. J. Clean. Prod. 2017, 147, 44-56. [CrossRef]

50. Domańska, A.; Żukowska, B.; Zajkowski, R.J.P.E. Green entrepreneurship as a connector among social, environmental and economic pillars of sustainable development. Why some countries are more agile? Probl. Ekorozw. 2018, 13, 67-76.

51. Bae, T.J.; Qian, S.; Miao, C.; Fiet, J.O. The relationship between entrepreneurship education and entrepreneurial intentions: A meta-analytic review. Entrep. Theory Pract. 2014, 38, 217-254. [CrossRef]

52. Fayolle, A.; Liñán, F.; Moriano, J.A. Beyond entrepreneurial intentions: Values and motivations in entrepreneurship. Int. Entrep. Manag. J. 2014, 10, 679-689. [CrossRef]

53. Muñoz, P.; Kibler, E.; Mandakovic, V.; Amorós, J.E. Local entrepreneurial ecosystems as configural narratives: A new way of seeing and evaluating antecedents and outcomes. Res. Policy 2020, 104065. [CrossRef]

54. Schumpeter, J.A. The Economics and Sociology of Capitalism; Princeton University Press: Princeton, NJ, USA, 1991.

55. Grant, R. The Resource-Based Theory of Competitive Advantage: Implications for Strategy Formulation. Calif. Manag. Rev. 1999, 10, 3-23. [CrossRef]

56. Alvarez, S.A.; Busenitz, L.W. The entrepreneurship of resource-based theory. J. Manag. 2001, 27, 755-775. [CrossRef]

57. Smirat, I.M.H.; Mohd Shariff, M.N. Research, Strategy, structure, and family firm performance: The relationships of the resourcebase view and the contingency approach. Aust. J. Bus. Manag. Res. 2014, 4, 1.

58. Schmitt, A.; Rosing, K.; Zhang, S.X.; Leatherbee, M. A dynamic model of entrepreneurial uncertainty and business opportunity identification: Exploration as a mediator and entrepreneurial self-efficacy as a moderator. Entrep. Theory Pract. 2017, 42, 835-859. [CrossRef]

59. Gerlach, A. Management, Sustainable entrepreneurship and innovation. Soc. Responsib. Environ. Manag. $2003,29$.

60. Kane, G.C.; Palmer, D.; Phillips, A.N.; Kiron, D. Winning the digital war for talent. MIT Sloan Manag. Rev. $2017,58,17$.

61. Srivastava, A.; Bartol, K.M.; Locke, E.A. Empowering leadership in management teams: Effects on knowledge sharing, efficacy, and performance. Acad. Manag. J. 2006, 49, 1239-1251. [CrossRef]

62. Käser, P.A.; Miles, R.E. Understanding knowledge activists' successes and failures. Long Range Plan. 2002, 35, 9-28. [CrossRef]

63. Jilani, M.M.A.K.; Fan, L.; Islam, M.T.; Uddin, A. The influence of knowledge sharing on sustainable performance: A moderated mediation study. Sustainability 2020, 12, 908. [CrossRef]

64. Yan, J.; Meng, Y.; Yang, X.; Luo, X.; Guan, X. Privacy-preserving localization for underwater sensor networks via deep reinforcement learning. IEEE Trans. Inf. Forensics Secur. 2020, 16, 1880-1895. [CrossRef]

65. Abbas, J.; Hussain, I.; Hussain, S.; Akram, S.; Shaheen, I.; Niu, B. The impact of knowledge sharing and innovation upon sustainable performance in islamic banks: A mediation analysis through an SEM approach. Sustainability 2019, 11, 4049. [CrossRef]

66. Bock, G.W.; Kim, Y.G. Breaking the myths of rewards: An exploratory study of attitudes about knowledge sharing. Info. Resour. Manag. J. 2002, 15, 14-21. [CrossRef]

67. Setini, M.; Yasa, N.N.K.; Supartha, I.W.G.; Giantari, I.G.A.K.; Rajiani, I. The passway of women entrepreneurship: Starting from social capital with open innovation, through to knowledge sharing and innovative performance. J. Open Innov. Technol. Mark. Complex. 2020, 6, 25. [CrossRef]

68. Pezeshkan, A.; Fainshmidt, S.; Nair, A.; Frazier, M.L.; Markowski, E. An empirical assessment of the dynamic capabilitiesperformance relationship. J. Bus. Res. 2016, 69, 2950-2956. [CrossRef]

69. Schmitt, U. Supporting the sustainable growth of SMEs with content-and collaboration-based personal knowledge management systems. J. Entrep. Innov. Emerg. Econ. 2018, 4, 1-21. [CrossRef] 
70. Mudalige, D.; Ismail, N.A.; Malek, M.A. Exploring the role of individual level and firm level dynamic capabilities in SMES' internationalization. J. Int. Entrep. 2018, 17, 41-74. [CrossRef]

71. Eikelenboom, M.; de Jong, G. The impact of dynamic capabilities on the sustainability performance of SMEs. J. Clean. Prod. 2019, 235, 1360-1370. [CrossRef]

72. Gao, H.; Hsu, P.-H.; Li, K.; Zhang, J. The real effect of smoking bans: Evidence from corporate innovation. J. Financ. Quant. Anal. 2018, 55, 387-427. [CrossRef]

73. Gonzalez, R.V.D. Effects of learning culture and teamwork context on team performance mediated by dynamic capability. J. Knowl. Manag. 2021. [CrossRef]

74. Hameed, K.; Arshed, N.; Yazdani, N.; Munir, M. Motivating business towards innovation: A panel data study using dynamic capability framework. Technol. Soc. 2021, 65, 101581. [CrossRef]

75. Beltramino, N.S.; García-Perez-de-Lema, D.; Valdez-Juárez, L.E. The structural capital, the innovation and the performance of the industrial SMES. J. Intel. Cap. 2020, 21, 913-945. [CrossRef]

76. Sunny, S.A.; Shu, C. Investments, incentives, and innovation: Geographical clustering dynamics as drivers of sustainable entrepreneurship. Small Bus. Econ. 2017, 52, 905-927. [CrossRef]

77. Fernandes, C.I.I.; Veiga, P.M.; Peris-Ortiz, M.; Rueda-Armengot, C. What impact does innovation and sustainable entrepreneurship have on competitiveness? Int. J. Soc. Ecol. Sustain. Dev. 2017, 8, 56-66. [CrossRef]

78. Flatten, T.C.; Engelen, A.; Zahra, S.A.; Brettel, M. A measure of absorptive capacity: Scale development and validation. Eur. Manag. J. 2011, 29, 98-116. [CrossRef]

79. Kostopoulos, K.; Papalexandris, A.; Papachroni, M.; Ioannou, G. Absorptive capacity, innovation, and financial performance. J. Bus. Res. 2011, 64, 1335-1343. [CrossRef]

80. Sciascia, S.; D'Oria, L.; Bruni, M.; Larrañeta, B. Entrepreneurial Orientation in low- and medium-tech industries: The need for Absorptive Capacity to increase performance. Eur. Manag. J. 2014, 32, 761-769. [CrossRef]

81. Sulistyo, H. Siyamtinah Innovation capability of SMEs through entrepreneurship, marketing capability, relational capital and empowerment. Asia Pac. Manag. Rev. 2016, 21, 196-203. [CrossRef]

82. Augier, M.; Teece, D.J. Dynamic Capabilities and the Role of Managers in Business Strategy and Economic Performance. Organ. Sci. 2009, 20, 410-421. [CrossRef]

83. Albort-Morant, G.; Henseler, J.; Cepeda-Carrión, G.; Leal-Rodríguez, A.L. Potential and Realized Absorptive Capacity as Complementary Drivers of Green Product and Process Innovation Performance. Sustainability 2018, 10, 381. [CrossRef]

84. Fang, E.; Zou, S. Antecedents and consequences of marketing dynamic capabilities in international joint ventures. J. Int. Bus. Stud. 2009, 40, 742-761. [CrossRef]

85. Dzhengiz, T.; Niesten, E.; Dzhengiz, T. Competences for Environmental Sustainability: A Systematic Review on the Impact of Absorptive Capacity and Capabilities. J. Bus. Ethics 2019, 162, 881-906. [CrossRef]

86. Aboelmaged, M.; Hashem, G. Absorptive capacity and green innovation adoption in SMEs: The mediating effects of sustainable organisational capabilities. J. Clean. Prod. 2019, 220, 853-863. [CrossRef]

87. Zhai, Y.-M.; Sun, W.-Q.; Tsai, S.-B.; Wang, Z.; Zhao, Y.; Chen, Q. An Empirical Study on Entrepreneurial Orientation, Absorptive Capacity, and SMEs' Innovation Performance: A Sustainable Perspective. Sustainability 2018, 10, 314. [CrossRef]

88. Amui, L.B.L.; Jabbour, C.J.C.; Jabbour, A.B.L.D.S.; Kannan, D. Sustainability as a dynamic organizational capability: A systematic review and a future agenda toward a sustainable transition. J. Clean. Prod. 2017, 142, 308-322. [CrossRef]

89. Saunila, M. Innovation capability in SMEs: A systematic review of the literature. J. Innov. Know. 2020, 5, 260-265. [CrossRef]

90. Akter, S.; Jamal, N.; Ashraf, M.; McCarthy, G.; Varsha, P. The rise of the social business in emerging economies: A new paradigm of development. J. Soc. Entrep. 2019, 11, 282-299. [CrossRef]

91. Nave, A.; Franco, M. University-Firm cooperation as a way to promote sustainability practices: A sustainable entrepreneurship perspective. J. Clean. Prod. 2019, 230, 1188-1196. [CrossRef]

92. Mousavi, S.; Bossink, B.; van Vliet, M. Dynamic capabilities and organizational routines for managing innovation towards sustainability. J. Clean. Prod. 2018, 203, 224-239. [CrossRef]

93. Sibindi, N. Dynamic managerial capabilities as antecedent of corporate entrepreneurship: A conceptual model. J. Entrep. Innov. 2021, 2. [CrossRef]

94. Rebs, T.; Thiel, D.; Brandenburg, M.; Seuring, S. Impacts of stakeholder influences and dynamic capabilities on the sustainability performance of supply chains: A system dynamics model. J. Bus. Econ. 2019, 89, 893-926. [CrossRef]

95. Inigo, E.A.; Albareda, L.; Ritala, P. Business model innovation for sustainability: Exploring evolutionary and radical approaches through dynamic capabilities. Ind. Innov. 2017, 24, 515-542. [CrossRef]

96. Hashim, N.A.B.; Raza, S.; Minai, M.S. Relationship between entrepreneurial competencies and small firm performance: Are dynamic capabilities the missing link? Acad. Strat. Manag. J. 2018, 17, 1-10.

97. Akkaya, B.; Üstgörül, S. Sustainability of SMEs and health sector in a dynamic capabilities perspective. Chall. Oppor. SMEs Ind. 2020, 43-64. [CrossRef]

98. Asante, E.A.; Affum-Osei, E. Entrepreneurship as a career choice: The impact of locus of control on aspiring entrepreneurs' opportunity recognition. J. Bus. Res. 2019, 98, 227-235. [CrossRef] 
99. Creswell, J.W.; Plano Clark, V.L.; Gutmann, M.L.; Hanson, W.E. An Expanded Typology for Classifying Mixed Methods Research into Designs. Available online: https://us.corwin.com/sites/default/files/upm-binaries/19291_Chapter_7.pdf (accessed on 8 August 2021).

100. Bryman, A. Barriers to integrating quantitative and qualitative research. J. Mix. Meth. Res. 2007, 1, 8-22. [CrossRef]

101. Brislin, R.W. Back-translation for cross-cultural research. J. Cross. Psych. 1970, 1, 185-216. [CrossRef]

102. Yusr, M.; Mokhtar, S.S.M.; Perumal, S.; Abdullateef, A.O.; Fathilah, R.; Yunus, N.K.Y. Managing absorptive capacity to enhance the influence of TQM practices on product innovation performance. Int. J. Econ. Res. 2017, 14, 325-332.

103. Hair, J.F.; Ringle, C.M.; Sarstedt, M. PLS-SEM: Indeed a silver bullet. J. Market. Theory Pract. 2011, 19, 139-152. [CrossRef]

104. Hair, J.F., Jr.; Sarstedt, M.; Hopkins, L.; Kuppelwieser, V.G. Partial least squares structural equation modeling (PLS-SEM): An emerging tool in business research. Euro. Bus. Rev 2014, 26, 106-121. [CrossRef]

105. Hsu, M.-H.; Ju, T.L.; Yen, C.-H.; Chang, C.-M. Knowledge sharing behavior in virtual communities: The relationship between trust, self-efficacy, and outcome expectations. Int. J. Hum. Comput. Stud. 2007, 65, 153-169. [CrossRef]

106. Hurley, R.F.; Hult, G.T.M. Innovation, market orientation, and organizational learning: An integration and empirical examination. J. Mark. 1998, 62, 42-54. [CrossRef]

107. Leal-Rodriguez, A.L.; Ariza-Montes, A.; Roldán, J.L.; Leal-Millan, A. Absorptive capacity, innovation and cultural barriers: A conditional mediation model. J. Bus. Res. 2014, 67, 763-768. [CrossRef]

108. Atuahene-Gima, K. Resolving the capability-rigidity paradox in new product innovation. J. Market. 2005, 69, 61-83. [CrossRef]

109. Kuckertz, A.; Kollmann, T.; Krell, P.; Stöckmann, C. Understanding, differentiating, and measuring opportunity recognition and opportunity exploitation. Int. J. Entrep. Behav. Res. 2017, 23, 78-97. [CrossRef]

110. Ab Hamid, M.R.; Sami, W.; Sidek, M.H.M. Discriminant Validity Assessment: Use of Fornell \& Larcker criterion versus HTMT Criterion. J. Phys. Conf. Ser. 2017, 890, 012163. [CrossRef]

111. Fornell, C.; Larcker, D.F. Evaluating structural equation models with unobservable variables and measurement error. J. Market. Res. 1981, 18, 39-50. [CrossRef]

112. Henseler, J.; Hubona, G.S.; Ray, P.A. Using PLS path modeling in new technology research: Updated guidelines. Ind. Manag. Data Syst. 2016, 116, 2-20. [CrossRef]

113. Fornell, C.; Bookstein, F.L. Two structural equation models: LISREL and PLS applied to consumer exit-voice theory. J. Market. Res. 1982, 19, 440-452. [CrossRef]

114. Ferreira, J.; Coelho, A. Dynamic capabilities, innovation and branding capabilities and their impact on competitive advantage and SME's performance in Portugal: The moderating effects of entrepreneurial orientation. Int. J. Innov. Sci. 2020, 12, 255-286. [CrossRef]

115. Yeganerad, M.; Tahery, M. The mediating effect of organizational culture and knowledge sharing on transformational leadership and Enterprise Resource Planning (ERP) systems success at the University. Res. Edu, Lead. Mana. 2014, 1, 137-163.

116. Jantunen, A.; Puumalainen, K.; Saarenketo, S.; Kyläheiko, K. Entrepreneurial orientation, dynamic capabilities and international performance. J. Int. Entrep. 2005, 3, 223-243. [CrossRef]

117. Chaudhary, S.; Batra, S. Absorptive capacity and small family firm performance: Exploring the mediation processes. J. Knowl. Manag. 2018, 22, 1201-1216. [CrossRef]

118. Han, J.; Won, E.-J.; Kang, H.-M.; Lee, M.-C.; Jeong, C.-B.; Kim, H.-S.; Hwang, D.-S.; Lee, J.-S. Marine copepod cytochrome P450 genes and their applications for molecular ecotoxicological studies in response to oil pollution. Mar. Pollut. Bull. 2017, 124, 953-961. [CrossRef] [PubMed]

119. Pezeshkan, A.; Smith, A.; Fainshmidt, S.; Sedeh, A.A. National business systems and firm innovation: A study of developing economies. J. Bus. Res. 2016, 69, 5413-5418. [CrossRef]

120. Bamel, U.K.; Bamel, N. Organizational resources, KM process capability and strategic flexibility: A dynamic resource-capability perspective. J. Knowl. Manag. 2018, 22, 1555-1572. [CrossRef]

121. Sanz-Velasco, S.A. Opportunity development as a learning process for entrepreneurs. Int. J. Entrep. Behav. Res 2006, 12, $251-271$. [CrossRef] 